\title{
Pre-service Science Teachers' Reflections of Secondary Science Education: A Case Study of a University of Technology
}

\author{
Motshidisi Lekhu*, Sheila Matoti \\ Department of Mathematics, Science and Technology Education, Central University of Technology, Free State, Bloemfontein, South Africa
}

*Corresponding Author: mlekhu@cut.ac.za

\section{ABSTRACT}

This non-experimental exploratory survey examined pre-service science teachers' self-efficacy beliefs and professional identity as influenced by their secondary school years learning experiences. A convenience sample of 60 undergraduate science student teachers participated in this study. An open-ended questionnaire on secondary school science experiences survey regarding the influences of school years' learning experiences on their current pedagogic practices. Survey data were analyzed using descriptive and inferential statistics and qualitative data were thematically analyzed. The findings suggest that pre-service science teachers perceive their self-efficacy as science teachers to be influenced by the teaching approaches used by their secondary school teachers to target learners' interests which include making science relevant to life and targeting learners' misconceptions in science. Similarly, they perceive the development of their professional identity to be influenced by their prior experiences as learners and observing their secondary school teachers' affective domain including their enthusiasm and positive attitude toward science. Recommendations are made to teacher education programs to promote use of reflective journals.

KEY WORDS: pre-service teacher; professional identity; science experience; teacher educator; teaching efficacy beliefs

\section{INTRODUCTION}

$\mathbf{P}$ re-service teachers' school years or prior learning experiences may influence their pedagogy beliefs as they undergo professional preparation (Thomas et al., 2001). Teaching science requires an understanding of how to teach the content, that is, student teachers need sufficient pedagogical content knowledge (PCK) to be effective practitioners. PCK development includes learning about strategies and approaches, from reflective classroom experience (Bartholomew et al., 2011). However, the specific ways in which school years' learning might influence developing pedagogic competencies of trainee pre-service science teachers are less well known. It might be that school years learning underlies how teachers under preparation appreciate alternative pedagogies; these preconceptions may be difficult to change even with extensive educational courses and teaching experience (Lotter, 2004). However, Lotter alerts that without adequate support, pre-service teachers may revert back to the way they were taught instead of trying to incorporate new teaching techniques if they are uncomfortable or uncertain about their abilities. Consequently, Hoover (1996) emphasizes that teachers teach as they are taught, not as they are told to teach. Nonetheless, attempts to identify and harness positive school years' learning experiences to support current teaching practices would make for effective science teaching. This study sought to determine how pre-service science teachers' secondary school education could be used as prior knowledge to improve and enhance their science teaching efficacy beliefs.

\section{RELATED LITERATURE AND THEORETICAL FRAMEWORK}

Constructivism represents one of the big ideas in education. Its implications for how teachers teach and learn to teach are enormous. If efforts in reforming education for all students are to succeed, then we must focus on students. Prior knowledge need not be only knowledge of the content, although that is the most critical type of knowledge to monitor. Knowledge of popular culture or current events can be used to great advantage as well in the same ways (Svinicki, 1994).

In as much as beginning a class with a review of what was done before helps activate prior knowledge, students entering teacher education programs can use their experiences to strengthen old information with the new one they acquire during their training. This is because learning of new knowledge is dependent on what is already known. In other words, knowledge is constructed first by observing and recognizing events (Novak and Gowin, 1984). For pre-service teachers to learn meaningfully, they must relate new knowledge to their relevant prior knowledge. It is thus imperative that appropriate teaching methods and strategies are utilized in the classrooms. This is in support of Ausubel's (1968) statement, "The most important single factor influencing learning is what the learner already knows. Ascertain this and teach them accordingly" (p. vi). It is thus important to acknowledge and recognize the knowledge that students bring to class and move from what they know towards what they do not know. There is no tabula 
rasa on which new knowledge is etched. Rather, learners come to learning situations with knowledge gained from previous experience, and that prior knowledge influences what new or modified knowledge they will construct from new learning experiences (Hoover, 1996). Fundamentally, constructivism says that people construct their own understanding and knowledge of the world through experiencing things and reflecting on those experiences (Brooks, 2004).

Hoover (1996) argues that social constructivism has important implications for teaching and learning. First, teaching cannot be viewed as the transmission of knowledge from enlightened to unenlightened. Therefore, teachers have to be knowledgeable of their subject. Second; learning is active rather than passive. Student teachers confront their understanding in light of what they encounter in the new learning situation. If what they encounter is inconsistent with their current understanding, their understanding can change to accommodate new experience. Third, if student teachers must apply their current understandings in new situations to build new knowledge, then lecturers must engage students in learning, bringing student teachers' current understandings to the forefront. Lecturers can ensure that learning experiences incorporate problems that are important to student teachers, not those that are primarily important to lecturers and the educational system. Fourth, if new knowledge is actively built, then time is needed to build it. Ample time facilitates student teachers' reflection about new experiences, how those experiences line up against current understandings, and how a different understanding might provide students with an improved (not "correct") view of the world (Hoover, 1996).

Constructivism, with specific reference to science education is defined by Tsai (2002) as a sound theory to help science educators understand how students learn science as well as to explicate the practice of science and science teaching. Lee (2006) asserts that constructivism has changed science education to a great extent. It shows science educators how people learn science. This means that science is best taught by helping students construct knowledge, and science is learnt through constructing personal understanding. For science education to be effective it must be noted that knowledge cannot simply be transferred from teachers to students, but it has to be conceived.

\section{Relationship between Constructs of the Study}

A conceptual design of the study linking prior knowledge, reflection, teacher training, as well as professional identity and self-efficacy beliefs is shown in Figure 1.

Reflective practice is critical to effective teaching. It is defined as a process associated with professional learning, which includes effective reflection and the development of metacognition, and leads to decisions for action, learning, achievement of goals, and changes to immediate and future practice (Hegarty, 2011). Self-efficacy beliefs are defined as "the belief in one's capabilities to organize and execute the courses of action required to manage prospective situations"

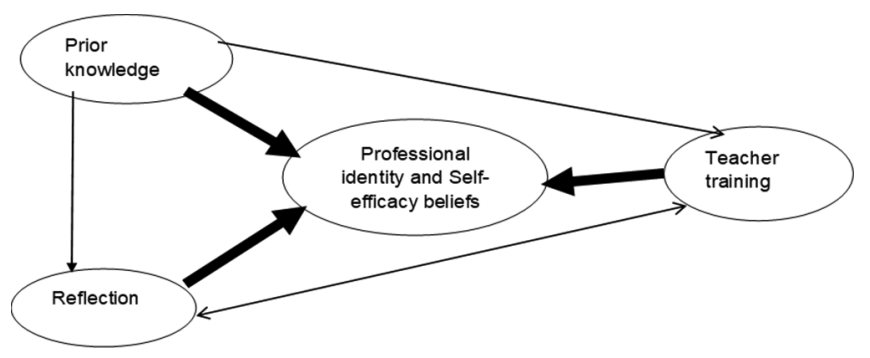

Figure 1: Conceptual design of the interrelationship between priorknowledge, students' reflection, teacher training, professional and self-efficacy beliefs

(Bandura, 1995. p. 2). These beliefs are believed to predict future behavior (Hoy, 2004). For instance, if a teacher believes that he or she is capable of managing his or her classroom and conducting meaningful lessons, he or she will more likely do just that. Effective learning of science by learners is directly influenced by teacher reflection in action, confidence, and competence (Midgley et al., 1989, Ashton and Webb, 1986 cited in Schiver, 1993, Taimalu and Oim, 2005). In light of this study, student teachers' reflection on secondary science education and teacher training experiences would greatly influence their self-efficacy beliefs and professional identity. Prior pedagogic learning is important to new learning and the development of a professional identity and also teaching self-efficacy beliefs.

Various studies have been carried out on pre-service elementary science teaching efficacy (Flores, 2015; Otero and Nathan, 2003) and a few on secondary sciences education experiences (Hudson et al., 2010; Hudson and Kidman, 2008; Finson et al., 2006). According to McGee and Cooper (2010) in Bartholomew et al. (2011), there is evidence that supports the view that new teachers have a positive impact on their students' learning when student teachers implement the practices they have learnt during their initial teacher education programs (Bartholomew et al., 2011).

\section{Aim of the Study}

This study focused on pre-service science teachers' reflections of their secondary school science education prior learning experiences, and how these experiences were used as prior knowledge to improve and enhance their science teaching efficacy beliefs.

\section{Research Question}

This study sought to answer the following research question:

- How do self-reported prior learning experiences of secondary school pre-service science teachers influence their self-perceived professional development and selfefficacy?

\section{Hypotheses}

- There is no significant difference between males and females on approaches targeting learners' interest

- There is no significant difference between male and female teachers' affective domain 
- There is no significant difference between males and females on teachers' articulation of concepts

- There is no significant difference between males and females on the selection of topics

- There is no significant difference between male and female teachers on teaching practices.

\section{METHODOLOGY}

\section{Research Design}

This study used a non-experimental, descriptive, and exploratory quantitative design to determine how pre-service science teachers' prior learning experiences influence their perceived professional development and their self-efficacy. The purpose of an exploratory approach is to use initial, qualitative phase to identify ideas and beliefs to design the quantitative part of the study, while a descriptive approach assesses the nature of existing conditions and provides a summary of an existing phenomenon using numbers to characterize a group (McMillan and Schumacher, 2006).

\section{Participants and Setting}

Respondents were a convenience sample of 85 students enrolled for a 4-year undergraduate Bachelor of Education degree, in the Natural Sciences Programme at a university of technology. Of these, 60 students who majored in physical sciences completed the study. Sixty-two percent $(62 \%)$ of the students were males and $38 \%$ were females. Thirty percent $(30 \%)$ of the students were under 22 years old, while $68 \%$ were above 22 years, the remaining $2 \%$ did not indicate their age.

\section{Instrument}

The students completed an open-ended questionnaire survey on remembering their secondary school science learning experiences. This study was adapted from Hudson et al. (2010). The measure includes questions on recall of memories about science teaching and learning while they were still learners at secondary schools. Responses are on a 5-point Likert type scale of agreement ranging from 1 to $5(1=$ strongly disagree [SD], and $5=$ strongly agree [SA]). A previous study reported a Cronbach's alpha internal consistency of 0.88 for scores from the instrument (Hudson et al., 2010). Student teachers were further requested to write a narrative on how they will use their high school experiences to improve on their future practice. They also self-reported their demographics.

\section{Data Collection Procedures}

The close structured questionnaires were administered during a physical science didactics class in the presence of the researcher. The questionnaire was piloted to eliminate ambiguity. Cronbach's alpha was used to compute the reliability of the instrument.

\section{Ethical Issues}

Permission to conduct the study was sought from and approved by the institution. Participation in the study was voluntary. The benefits of participating in the study were explained to the participants. The respondents were also assured of the confidentiality of their responses.

\section{Data Analysis}

Microsoft Excel and GraphPad software were used to analyze the data. Descriptive statistics (frequencies, means, and standard deviations) as well as inferential statistics (MannWhitney U) were computed to characterize how pre-service science teachers' prior learning experiences influence their professional development.

\section{FINDINGS}

The statements of the full scale were categorized into five themes, namely: Teachers' approaches targeting learners' interest, teachers' affective domain, teachers' articulation of concepts, selection of topics, and teaching practices. Tables 1-6 present the descriptive and inferential statistics for the study variables.

\section{Scale Results Per Category}

Approaches targeting learners' interests

There is no significant difference between males and females on approaches targeting learners' interest. The teachers' perception of relevance to life was ranked the highest prior learning influences $(M=4.40)$, whilst lesson planning was ranked the lowest $(\mathrm{M}=2.49)$.

A Mann-Whitney test was used to evaluate the hypothesis that male respondents would score higher, on the average, than female respondents on teachers' approaches targeting learners' interest. The results of this test were greater for males $(M d n=7)$ than females $(M d n=4), U=7, \rho=0.29834$. The

\begin{tabular}{|c|c|c|c|c|c|c|c|}
\hline \multirow[t]{2}{*}{ Item } & \multirow[t]{2}{*}{ I think I would remember science if my teacher } & \multicolumn{2}{|c|}{ Whole group } & \multicolumn{2}{|c|}{ Males } & \multicolumn{2}{|c|}{ Females } \\
\hline & & Mean & Rank & Mean & Rank & Mean & Rank \\
\hline 1 & Targeted my misconceptions about science & 3.62 & 4 & 3.95 & 4 & 3.69 & 6 \\
\hline 7 & Planned a lesson without worrying about my interests & 2.49 & 5 & 2.21 & 10 & 2.54 & 9 \\
\hline 15 & Considered my interests when devising a science activity & 3.56 & 3 & 3.89 & 5 & 3.31 & 8 \\
\hline 22 & Made science relevant to my life & 4.40 & 1 & 4.58 & 1 & 4.00 & 3 \\
\hline \multirow[t]{3}{*}{25} & Presented opportunities for independent studies in science & 3.87 & 2 & 4.28 & 2 & 3.62 & 7 \\
\hline & Average & 3.59 & & 3.78 & & 3.43 & \\
\hline & Mann-Whitney U p-value & \multicolumn{6}{|c|}{0.29834} \\
\hline
\end{tabular}

* $\rho<0.05 ; 1$ = Strongly disagree, 2 = Disagree, 3 = Uncertain, 4 = Agree, 5 = Strongly agree 


\begin{tabular}{|c|c|c|c|c|c|c|c|}
\hline \multirow[t]{2}{*}{ Item } & \multirow[t]{2}{*}{ I think I would remember science if my teacher } & \multicolumn{2}{|c|}{ Whole group } & \multicolumn{2}{|c|}{ Males } & \multicolumn{2}{|c|}{ Females } \\
\hline & & Mean & Rank & Male & Rank & Female & Rank \\
\hline 4 & Taught the lesson without too many explanations & 2.96 & 10 & 3.00 & 20 & 3.23 & 19 \\
\hline 5 & Facilitated group work with my peers & 3.93 & 7 & 4.06 & 11 & 4.00 & 12.5 \\
\hline 6 & Constructed science lessons that had practical and usable knowledge & 4.36 & 1 & 4.58 & 1 & 4.08 & 10 \\
\hline 8 & Provided hands-on science experiences & 4.20 & 4 & 4.32 & 6.5 & 3.92 & 15 \\
\hline 11 & Presented opportunities for me to copy lesson notes from the board & 3.70 & 8 & 3.68 & 16 & 4.23 & 9 \\
\hline 14 & Let me do the science activity without explaining the reason & 2.13 & 11 & 2.00 & 22 & 2.08 & 21 \\
\hline 17 & Let me experiment and discover concepts for myself & 3.62 & 9 & 3.95 & 14 & 3.54 & 17.5 \\
\hline 18 & Corrected me when I was not correct & 4.33 & 2 & 4.47 & 2.5 & 4.31 & 8 \\
\hline 23 & Took me on science excursions (e.g., museum, and planetarium) & 4.27 & 3 & 4.47 & 2.5 & 4.00 & 12.5 \\
\hline 24 & Told me I was wrong when I was wrong & 4.17 & 5 & 4.39 & 4 & 4.38 & 5 \\
\hline \multirow[t]{3}{*}{28} & Showed me how to record science results in a scientific way & 3.98 & 6 & 4.32 & 6.5 & 3.54 & 17.5 \\
\hline & Average & & & 3.93 & & 3.76 & \\
\hline & Mann-Whitney U p-value & \multicolumn{6}{|c|}{0.1902} \\
\hline
\end{tabular}

${ }^{*} \rho<0.05 ; 1$ = Strongly disagree, 2 = Disagree, 3 = Uncertain, 4 = Agree, 5 = Strongly agree

\begin{tabular}{|c|c|c|c|c|c|c|c|}
\hline \multirow[t]{2}{*}{ Item } & \multirow[t]{2}{*}{ I think I would remember science if my teacher } & \multicolumn{2}{|c|}{ Whole group } & \multicolumn{2}{|c|}{ Males } & \multicolumn{2}{|c|}{ Females } \\
\hline & & Mean & Rank & Mean & Rank & Mean & Rank \\
\hline 2 & Organized science activities that involved dissection & 4.00 & 1 & 4.22 & 1 & 3.62 & 7.5 \\
\hline 12 & Conducted lessons that included interactivity with animals & 2.62 & 6 & 2.79 & 11 & 2.31 & 12 \\
\hline 19 & Provided a wide selection of science topics & 3.82 & 4 & 4.11 & 3 & 3.77 & 6 \\
\hline 20 & Conducted lessons that included interactivity with plants & 3.27 & 5 & 3.26 & 9 & 2.85 & 10 \\
\hline 26 & Demonstrated circuitry & 3.94 & 2 & 4.17 & 2 & 3.62 & 7.5 \\
\hline \multirow[t]{3}{*}{27} & Taught me about life cycles & 3.85 & 3 & 4.05 & 4 & 3.92 & 5 \\
\hline & Average & & & 3.77 & & 3.35 & \\
\hline & Mann-Whitney U p-value & \multicolumn{6}{|c|}{0.17384} \\
\hline
\end{tabular}

${ }^{*} \rho<0.05 ; 1$ = Strongly disagree, 2 = Disagree, 3 = Uncertain, 4 = Agree, 5 = Strongly agree

\begin{tabular}{|c|c|c|c|c|c|c|c|}
\hline \multirow[t]{2}{*}{ Item } & \multirow[t]{2}{*}{ I think I would remember science if my teacher } & \multicolumn{2}{|c|}{ Whole group } & \multicolumn{2}{|c|}{ Males } & \multicolumn{2}{|c|}{ Females } \\
\hline & & Mean & Rank & Mean & Rank & Mean & Rank \\
\hline 3 & Was enthusiastic about teaching science & 4.13 & 2 & 4.05 & 3 & 4.00 & 4.5 \\
\hline 16 & Had a positive attitude towards science & 4.11 & 3 & 4.53 & 1.5 & 4.00 & 4.5 \\
\hline \multirow[t]{3}{*}{21} & Organized lessons that required use of science equipment & 4.22 & 1 & 4.53 & 1.5 & 3.92 & 6 \\
\hline & Average & 4.15 & & 4.39 & & 3.97 & \\
\hline & Mann-Whitney U p-value & \multicolumn{6}{|c|}{ - } \\
\hline
\end{tabular}

results of the test show that there is no significant difference between males and females on the teachers' approaches targeting learners' interest.

\section{Science teaching practice}

There is no significant difference between male and female teachers' affective domain. Teachers' lesson plans with practical and usable knowledge were ranked the highest prior learning influences $(M=4.36)$, while letting learners' activities without explanation were ranked the lowest $(\mathrm{M}=2.13)$.

A Mann-Whitney test was used to evaluate the hypothesis that male respondents would score higher, on the average, than female respondents on teachers' science teaching practices. The results of this test were greater for males $(M d n=16.5)$ than females $(M d n=10.5), U=40, \rho=0.1902$. The results of the test show that there is no significant difference between males and females on the teachers' science teaching practices.

\section{Selection of topics}

There is no significant difference between males and females on teachers' articulation of concepts. Teachers' selection of topics involving dissection was ranked highest $(M=4.00)$, while those involving interactivity with animals $(\mathrm{M}=2.62)$ was ranked the lowest prior learning influences. 


\begin{tabular}{|c|c|c|c|c|c|c|c|}
\hline \multirow[t]{2}{*}{ Item } & \multirow[t]{2}{*}{ I think I would remember science if my teacher } & \multicolumn{2}{|c|}{ Whole group } & \multicolumn{2}{|c|}{ Males } & \multicolumn{2}{|c|}{ Females } \\
\hline & & Mean & Rank & Mean & Rank & Mean & Rank \\
\hline 9 & Talked about the science concepts in fine detail. & 4.02 & 2 & 4.17 & 4 & 3.62 & 6 \\
\hline 10 & Explained abstract science concepts in simple terms & 4.33 & 1 & 4.58 & 1 & 4.54 & 2 \\
\hline \multirow{3}{*}{13} & Articulated clearly the purposes for the science lesson & 3.95 & 3 & 4.32 & 3 & 3.92 & 5 \\
\hline & Average & 4.10 & & 4.36 & & 4.03 & \\
\hline & Mann-Whitney U & \multicolumn{6}{|c|}{-} \\
\hline
\end{tabular}

${ }^{*} \rho<0.05 ; 1$ = Strongly disagree, 2 = Disagree, 3 = Uncertain, 4 = Agree, 5 = Strongly agree

\section{Table 6: Summary of descriptive statistics on the five categories}

\begin{tabular}{|c|c|c|c|c|c|c|c|c|c|}
\hline \multirow[t]{2}{*}{ Category } & \multicolumn{3}{|c|}{ Whole group } & \multicolumn{3}{|c|}{ Males } & \multicolumn{3}{|c|}{ Females } \\
\hline & Mean & SD & Rank & Mean & SD & Rank & Mean & SD & Rank \\
\hline Targeting learners' interest & 3.59 & 1.14 & 4 & 3.78 & 0.92 & 6 & 3.43 & 0.56 & 9 \\
\hline Selection of topics & 3.58 & 0.96 & 5 & 3.77 & 0.60 & 7 & 3.35 & 0.63 & 10 \\
\hline Teacher's affective domain & 4.15 & 1.11 & 1 & 4.39 & 0.29 & 1 & 3.97 & 0.05 & 4 \\
\hline Concepts from teachers & 4.10 & 1.00 & 2 & 4.36 & 0.21 & 2 & 4.03 & 0.47 & 3 \\
\hline Science teaching practice & 3.79 & 1.11 & 3 & 3.93 & 0.79 & 5 & 3.76 & 0.66 & 8 \\
\hline
\end{tabular}

A Mann-Whitney test was used to evaluate the hypothesis that male respondents would score higher, on the average, than female respondents on the selection of topics. The results of this test were greater for males $(\mathrm{Mdn}=16.5)$ than females $(\mathrm{Mdn}=10.5), \mathrm{U}=40, \rho=0.1902$. The results of the test show that there is no significant difference between males and females on the selection of topics.

\section{Teachers' affective domain}

There is no significant difference between males and females on the selection of topics. Teachers organized lessons requiring the use of science equipment were ranked the highest prior learning influences $(\mathrm{M}=4.22)$, while their positive attitude toward science was ranked the lowest $(M=4.11)$. Male students' average mean score $(M=4.39)$ was high in this category compared to female students who scored a mean of 3.97 .

\section{Teachers' articulation of concepts}

Secondary school teachers perceived prior school experiences to influence their concepts that explained abstract science concepts in simple terms was ranked the highest $(\mathrm{M}=4.33)$ and the concepts that articulated clearly the purposes for the science lesson ranked the lowest $(\mathrm{M}=3.95)$. The male students ranked the higher that the females in all the three items of this category.

Table 6 summarizes data according to the five categories in which the statements have been categorized for the whole group, males and females, respectively.

\section{Open-Ended Questions Analysis}

The followings are the themes that emerged from open-ended questions.

Theme 1: Positive science teaching experiences

Themes that emerged from the pre-service teachers' most memorable learning experiences include performing experiments, attending science expos and taking excursions to different science institutions and centers as stated below:

"We attended a science expo where I gained knowledge about how science is part of our daily lives"

"We performed color change experiment with indicators. It was exciting to observe color changes, a successful experiment reminding us of rainbow."

The reason why the mentioned experiences were memorable was because it was their first time to experience real science. This exposure to science sparked their interest and love for the subject as confirmed by the following statements:

"Visiting Maropeng Cradle of Mankind, I learnt a lot about evolution, and even today I still remember a lot from that"

"Doing a Chemistry practical on preparing hydrogen sulfide gas, the entire laboratory was filled with its foul odor of rotten eggs"

Theme 2: Negative science education experiences

The pre-service teachers also indicated some bad memories they had in their secondary school learning of science. These included being taught by incompetent and not so enthusiastic teachers. The following excerpts emphasized how the science teacher could play a role in discouraging students toward science:

"My teacher was not eager to make science interesting; there was no difference between science and English classes."

"I realized that science is around us and it is fascinating. Teachers were unable to answer some of my questions due to my curiosity"

The most prevalent bad memory was lack of hands-on laboratory activities where they were forced to either do 
observations or watch videos of experiments. In some instances, pre-service teachers were exposed to hazardous situations that were also due to lack of proper supervision in the laboratory.

"When the Science learning facilitator from the Department of Education visited our school and performed a practical experiment. I was so embarrassed because the scientific names of apparatus used were not familiar to me"

"The teacher tried to conduct an experiment without the correct procedure... everything almost got burned down."

Theme 3: Improvements toward science education

Pre-service teachers who had positive experiences gave all the credit to their secondary school teachers. They will continue to inspire their learners by being passionate, enthusiastic, and motivated:

"I was highly inspired by my teacher who had best ways of introducing lessons using concepts from other learning areas that learners mastered, for example, Reproduction."

"She would always come to class prepared, knowing what to do with all the energy. She always had interest in how learners are coping with the subject."

"Science teachers give their all when it comes to educating children about the world they live in; they go beyond boundaries to ensure quality education"

Those who had negative experiences would improve the teaching and learning of science by teaching learners thoroughly, explaining abstract concepts, and correcting learners when they are wrong, and presenting them with opportunities to do practical work. The following excerpts show how some pre-service teachers felt that their own teachers did not give the teaching of science its well-deserved attention:

"I'll put my learners first, not to summarize lessons rushing off to complete the syllabus"

"Science was never fun, so I'll make it fun and understandable at the same time. I'll expose my learners to hands-on practical activities and organize science excursions."

Would you prefer to teach the way that you were taught?

While only $33 \%$ of the pre-service responded "yes" to this question, a remarkable $67 \%$ of the pre-service teachers preferred not to teach the way that they were taught for various reasons addressed in the previous question.

"NO! Telling without doing is not science. Working in groups where we all did not understand a concept, or rely on one person who might have an idea"

"Yes! Teaching strategies used by my teacher were the best and produced the best results; I'll then focus on slow but working learners and groom them."

What would you choose to change?
The majority of the pre-service teachers indicated that they were made to believe that science was a difficult subject during their school years. They, therefore, wanted to demystify science change the perception that science was for "smart" learners only. These pre-service teachers indicated that they do not want to make the same mistake made by the secondary school teachers of teaching learners only to pass to the next grade, but they will make them understand concepts thoroughly and apply knowledge to change their behavior. They intended to simplify concepts, assess their learners more often, relate schoolwork with day to day experiences, and allow learners to explore scientific adventures. They wanted to change their approach to learners without assuming that they know and they would encourage learners to have positive attitude toward science. Pre-service teachers were looking forward to introducing more practical work to their learners which will promote a positive scientific attitude and instill a sense of inquiry learning.

The only way a teacher learns to teach is through teaching, it is evident that the introduction of reflective practice during teacher education training will enhance teaching efficacy beliefs. Through reflection, pre-service teachers can develop knowledge and can therefore play a key role in the construction of new knowledge, and in the development of knowledge base which can advance their future professional practice (Osterman, 1990). In general, pre-service teachers are eager to structure the learning experiences in such a way that the nature of science becomes an inherent part of all teaching and learning situations and also to develop scientific temper among learners. This is in-line with the stipulated roles of a science teacher in the nature of science module that forms part of their physical science subject methodology.

\section{DISCUSSION}

The results showed that pre-service teachers' professional identity and self-efficacy beliefs were influenced by teachers' affective domain which was ranked the highest $(\mathrm{M}=4.15)$, followed by concepts from teachers $(M=4.10)$, science teaching practice $(M=3.79)$, teachers approaches targeting learners' interest $(\mathrm{M}=3.59)$, and finally the selection of topics $(\mathrm{M}=3.58)$. It is important to note that no significant difference between male and female pre-service teachers was found for all the five categories of the scale. However, in all the categories the male student teachers showed higher ranks than the female student teachers. In a study focusing on the development of students' professional identity, a difference in professional identity based on students' gender was found, while male students tend to attach more importance to discipline in the classroom, their female counterparts focus more on student involvement (Lamote and Engels, 2010).

The findings of the open-ended questions revealed that through the knowledge that the pre-service teachers gain during their initial teacher training, they want to promote inquiry learning even though they did not get such exposure during their secondary school years. This finding is supported by Samuel 
and Stephens (2000) that teacher educators need to learn much more about the "identity baggage" that student teachers bring with them into the professional arena. Much of this "baggage" has been acquired by student teachers during the formative stages of their lives. During their training, the transition from personal self to professional identity calls for a much closer understanding of the matrix of complex, contradictory, and complementary agendas that influence the making of a teacher (Samuel and Stephens, 2000). On the contrary, in their study examining pre-service teachers' previous experiences and visions about their future teaching, Gurbuzturk et al. (2009) revealed a significant association between pre-service teachers' visions about their future teaching and their views about their previous education experiences only at primary level. These findings suggest that pre-service teachers are not affected by their secondary school or university teachers' practices in terms of shaping their visions for future teaching (Gurbuzturk et al., 2009).

The findings suggest that teachers' affective domain $(M=4.15$, $\mathrm{SD}=1.11)$ as one of the identified categories, play a significant role in the development of professional identity. This finding is in line with the findings of the study by Haught et al. (2015) where students had more pleasant and positive memories for the subjects they planned to teach (Haught et al., 2015). Thus, trainers in constructivist professional development sessions should model learning activities that teachers can apply in their own classrooms. It is not enough for trainers to describe new ways of teaching and expect teachers to translate from talk to action; it is more effective to engage teachers in activities that will lead to new actions in classrooms (Hoover, 1996). This in turn will enhance their vicarious experience as a source of efficacy which will build the self-efficacy beliefs of preservice teachers.

The category on teachers' articulation of concepts was scored second highest $($ mean $=4.10, \mathrm{SD}=1.00)$. This score is in agreement with the open-ended question that required the respondents to indicate how they can use their own experience to improve the teaching and learning of science. Respondents perceived science to be very difficult and abstract; hence, they wished that their teachers would have simplified the science concepts to help them understand better. That is the main reason why most of the prospective teachers want to promote mastery learning by demystifying abstract science concepts and dealing away with the perception that science is difficult and only meant for smart learners. This undertaking is in line with one of the four main sources of efficacy, mastery experience as shown in the excerpt below:

"To master science, learners should be able to believe in their own understanding abilities and have sound curiosity toward acquiring knowledge about the universe"

In mastering experience, one's direct experiences help in the successful performance of tasks which reinforces optimistic self-efficacy perceptions. Mastery experiences are the most powerful source of efficacy information, according to Tschannen-Moran et al. (1998). The perception that a performance has been successful can raise efficacy beliefs and provide the source for the belief that future performances in a similar vein will also be successful (Cantrell and Young, 2003). The respondents are also in support of promoting not only their self-efficacy but also will focus equally on the outcome expectancy dimension that is concerned about learners' performance. According to McGee and Cooper (2010) in Bartholomew et al. (2011), there is evidence that supports the view that new teachers have a positive impact on their students' learning when student teachers implement the practices they have learned during their initial teacher education programs (Bartholomew et al., 2011).

Science teaching practice was the third highly ranked category $(\mathrm{M}=3.79, \mathrm{SD}=1.11)$. The majority of the respondents have mentioned that their best positive experience of their secondary science education would be when they performed practical experiments $($ mean $=4.36)$, when the teacher corrected them when they were not correct (mean $=4.33)$ and when they took science excursion $($ mean $=4.27)$. This exposure to the "real science" and proper guidance made them realize that science does exist. Their negative attitude was as a result of lack of resources and proper infrastructure, teachers who lacked content knowledge and seemed less interested in teaching science. This is supported by the lowest scored item 14 (I think I would remember science if my teacher let me do the science activity without explaining the reason) which resulted in their worst memory with mean $=2.13$. Likewise, Simmons (2016) revealed that most pre-service teachers reported that their undergraduate science content courses provided poor instructional models of reform-based science teaching and learning that were of little value in preparing them as science teachers (Simmons, 2016).

As prospective teachers, respondents want to make sure that they do not leave learners with unanswered questions and ensure that they correct their learners when they are wrong. They want to motivate and inspire their learners to love science not to ridicule them and make them feel that they do not qualify to do science. Motivation is one source of self-efficacy. Verbal persuasions at motivational discussions involve skillful persuaders who focus on an individual's skills, counteracting doubt and obsession with personal shortcomings and weaknesses. Social persuasion can provide information about the nature of teaching, give encouragement and strategies for overcoming obstacles, and provide specific feedback on a teacher's performance. Bandura (1997) suggests that the social framing of verbal persuasion is a critical factor that can influence efficacy. Evaluation that highlights personal capabilities may raise efficacy beliefs, whereas evaluation that focuses on shortcomings brings deficiencies into the spotlight and efficacy beliefs may be deflated (Cantrell and Young, 2003). These motivational discussions convince people to focus more on their skills that will assist them to be successful (Bandura, 1997 cited in Steyn and Mynhardt, 2008). Schön's concept of reflective practice incorporates a 
view of human motivation which assumes that individuals want to become more effective and that they naturally strive to improve their performance (Argyris and Schön, 1974 cited in Osterman, 1990).

The findings of this study are in line with Fuller's (1969) three progressive stages in beginning teacher development as outlined in Lotter (2004). The first stage is of "no concern" where pre-service teachers only have vague ideas about teaching and their ideas stem from their own experiences as students themselves, followed by "concern with self" where they are concerned with issues of their own adequacy as teachers in dealing with classroom control and the ability to teach the subject matter (Lotter, 2004). Finally, they reach a stage of 'concern with pupil' in which they are concerned with pupil learning and progress (Lotter, 2004). The two dimensions of self-efficacy beliefs, personal science teaching efficacy and science teaching outcome expectancy are represented by the second and the third stages, respectively.

\section{CONCLUSION}

The five categories, namely, teachers' approaches targeting learners' interest, teachers' affective domain, teachers' articulation of concepts, selection of topics, and teaching practices have both positive and negative impact on the pre-service teachers' professional identity and self-efficacy. Pre-service teachers with negative secondary school learning experiences will use their own school years' learning experiences and teacher training to build and develop positive professional identity and self-efficacy. This research has limitations because of the size of the sample, the findings cannot be generalized. Hence, a need for further research in other teacher education areas of specialization includes technology, computer science, languages, and social sciences. Consequently, this research would have implications on teacher education programs, where self-efficacy beliefs and professional identity could be enhanced by being embedding into the curriculum. This, in turn, might lead to the development of teachers who are reflective practitioners.

\section{REFERENCES}

Argyris, C., \& Schön, D.A. (1974). Theory in Practice: Increasing Professional Effectiveness. San Francisco: Jossey-Bass.

Ashton, P.T., \& Webb, R.B. (1986). Making a Difference: Teachers'Sense of Efficacy and Student Achievement. New York: Longman.

Ausubel, D.P. (1968). Educational Psychology: A Cognitive View. New York, United States: Holt, Rinehart \& Winston.

Bandura, A. (1995). Self-efficacy in Changing Societies. Cambridge, United Kingdom: Cambridge University Press.

Bandura, A. (1997). Self-efficacy: The Exercise of Control. New York, United States: Freeman \& Company.

Bartholomew, R., Moeed, A., \& Anderson, D. (2011). Changing science teaching practice in early career secondary teaching graduates. Eurasia Journal of Mathematics Science and Technology Education, 7(1), 53-61.

Brooks, J.G. (2004). Constructivism as a Paradigm for Teaching and Learning. $13^{\text {th }}$ ed. Available from: https://www.thirteen.org/edonline/ concept2class/constructivism/.

Cantrell, P., \& Young, S. (2003). Factors affecting science teaching efficacy of preservice. Journal of Science Teacher Education, 14(3), 177-192.
Finson, K., Pedersen, J., \& Thomas, J. (2006). Comparing science teaching styles to students' perceptions of scientists. School Science and Mathematics, 106(1), 8-15.

Flores, I.M. (2015). Developing pre-service teachers' self-efficacy through field- based science teaching practice with elementary students. Research in Higher Education Journal, 27, 1-19.

Fuller, F.F. (1969). Concerns of teachers: A developmental conceptualization. American Educational Research Journal, 6(2), 207-226.

Gurbuzturk, O., Duruhan, K., \& Nihat, S. (2009). Pre-service teachers' previous experiences and visions about their future teaching. Elementary Education Online, 8(3), 923-934.

Haught, P.A., Nardi, A.H., \& Walls, R.T. (2015). Preservice teachers academic memories of a school: A tool for learning. American Journal of Educational Research, 3(2), 166-172.

Hegarty, B. (2011). A Framework to Guide Professional Learning and Reflective Practice. (Unpublished Doctoral Dissertation. Australia: University of Wollongong. Available from: http://www.ro.uow.edu.au/ theses/3720. [Last accessed on 2020 May 08].

Hoover, W.A. (1996). The practice implications for constructivism. SEDL Letter, 9(3), 1-2. Available from: http://www.sedl.org/pubs/sedletter/ v093n03/practice.html. [Last accessed on 2020 May 08].

Hoy, A.W. (2004). What Do Teachers Need to Know About Self-efficacy? San Diego: Paper Presented at the Annual Meeting of the American Educational Research Association.

Hudson, P., \& Kidman, G. (2008). Making a Difference in Secondary Science Education. Sunshine Coast, Australia: Paper Presented at the Australian Teachers Education Association (ATEA) Conference.

Hudson, P., Usak, M., Fančovičová, J., Erdoğan, M., \& Prokop, P. (2010). Preservice teachers' memories of their secondary science education experiences. Journal of Science Education and Technology, 19(6), 546-552.

Lamote, C., \& Engels, N. (2010). The development of student teachers' professional identity. European Journal of Teacher Education, 33(1), 3-18.

Lee, M. (2006). What Does Constructivism Suggest for Science Education? United States: California State University.

Lotter, C. (2004). Preservice science teachers' concerns through classroom observations and student teaching: Special focus on inquiry teaching. Science Educator, 13(1), 29-38.

McMillan, J.H., \& Schumacher, S. (2006). Research in Education: Evidence Based Inquiry. London, United Kingdom: Pearson Education, Inc.

Midgley, C., Feldlaufer, H., \& Eccles, J. (1989). Change in teacher efficacy and student self and task-related beliefs in mathematics during the transition to junior high school. Journal of Educational Psychology, 81(2), 247-258.

Novak, J.D., \& Gowin, B.D. (1984). Learning How to Learn. Cambridge, United Kingdom: Cambridge University Press.

Osterman, K.F. (1990). Reflective practice: A new agenda. Education and Urban Society, 22(2), 133-152.

Otero, V., \& Nathan, M. (2003). Elementary pre-service teachers' conceptions of student prior-knowledge. In: Cummings, K., Marx, J., \& Franklin, S., (Eds.), Proceedings of the 2002 Physics Education Research Conference. Melville, NY: AIP Press. pp. 123-128.

Samuel, M., \& Stephens, D. (2000). Critical dialogues with self: Developing teacher identities and roles-a case study of South African student teachers. International Journal of Educational Research, 33(2), 475-491.

Schiver, M. (1993). A Comparison of Middle and Junior High Science Teachers' Level of Efficacy, and Knowledge of Developmentally Appropriate Curriculum and Instruction. Atlanta: Paper Presented at the Annual Meeting of the National Association for Research in Science Teaching.

Simmons, P. (2016). Teachers of Science: Beliefs and Practices of Graduate and Undergraduate Students. Philadelphia, PA: AAAS Annual Meeting.

Steyn, R., \& Mynhardt, J. (2008). Factors that influence the forming of self-evaluation and self-efficacy perceptions. South African Journal of Psychology, 38, 563-573.

Svinicki, M. (1994). What they don't know can Hurt them: The Role of Prior Knowledge. Available from: https://www.grad.uic.edu/ academic-support/ta-enrichment/uic-ta-handbook/uic-ta-handbook- 
what-they-dont-know-can-hurt-them-the-role-of-prior-knowledge-inlearning/.

Taimalu, M., \& Oim, O. (2005). Estonian teachers' beliefs on teacher efficacy and influencing factors. Trames, 9(2), 177-191.

Thomas, J.A., Pederson, J.E., \& Finson, K. (2001). Validating the drawa-science-test-checklist (DASTT-C): Exploring mental models and teacher beliefs. Journal of Science Teacher Education, 12(3), 295-310.

Tsai, C. (2002). Nested epistemologies: Science teachers' beliefs of teaching, learning and science. International Journal of Science Education, 24(8), 771-783.

Tschannen-Moran, M., Hoy, A.W., \& Hoy, W.K. (1998). Teacher efficacy: Its meaning and measure. Review of Educational Research, 68, 202-248. 